\title{
Problematika Penerapan Sistem Belajar Daring dan Luring Terhadap Anak pada Masa Pandemi Covid 19 dan New Normal
}

\author{
Agnesty Marcia $^{1 凶}$, Nurhafizah Nurhafizah ${ }^{1}$ \\ Pendidikan Anak Usia Dini, Universitas Negeri Padang, Indonesia(1) \\ DOI: $10.31004 /$ obsesi.v6i4.2206
}

\begin{abstract}
Abstrak
Belum optimalnya pelaksanaan pembelajaran anak usia dini khususnya di lembaga PAUD non Formal di masa pandemic covid 19 dan new normal. Disini dipaparkan bagaimana kendala yang dihadapi oleh anak kelompok bermain maupun pendidik dalam melaksanakan sistem belajar daring dan luring yang sudah diterapkan semenjak terjadinya masa pandemi covid 19 hingga memasuki masa kenormalan baru. Metode penelitian yang digunakan adalah Penelitian Kualitatif. Dalam penelitian ini yang menjadi instrumen penelitian adalah peneliti sendiri. Teknik pengumpulan data yang digunakan berupa observasi, wawancara dan dokumentasi. Adapun hasil dari penelitian ditemukan beberapa permasalahan yang dihadapi antara lain dalam penerapan sistem belajar daring dan luring belum optimal memenuhi prinsip-prinsip dan metode pembelajaran anak usia dini, belum optimal dalam menstimulasi gaya belajar anak, media pembelajaran yang digunakan menimbulkan kejenuhan dalam belajar, Peran pendidik tidak dapat digantikan oleh media, proses sosialisasi dengan teman dan pendidik tidak berjalan optimal serta respon orang tua dalam pelaksanaan pembelajaran tersebut.
\end{abstract}

Kata kunci: problematika; sistem belajar daring dan luring; new normal; anak usia dini

\begin{abstract}
The implementation of this learning is not yet optimal to meet the learning needs of early childhood, especially in non-formal PAUD institutions during the COVID-19 pandemic and the new normal. Here, it is explained how the obstacles faced by play group children and educators in implementing online and offline learning systems that have been implemented since the onset of the COVID-19 pandemic until entering a new normal period. The research method used is qualitative research. In this research, the research instrument is the researcher himself. Data collection techniques used in the form of observation, interviews and documentation. The results of the study found several problems faced, among others, in the application of online and offline learning systems that have not optimally met the principles and methods of early childhood learning, have not been optimal in stimulating children's learning styles, the learning media used causes boredom in learning, the role of educators media cannot be replaced, the socialization process with friends and educators does not run optimally and the response of parents in the implementation of the learning.

Keywords: Problematics; Online and Offline Learning Systems; early childhood; new normal
\end{abstract}

Copyright (c) 2022 Agnesty Marcia, Nurhafizah Nurhafizah

$\triangle$ Corresponding author :

Email Address : agnestymarchia@gmail.com (Padang, Indonesia)

Received 30 October 2021, Accepted 10 January 2022, Published 26 January 2022 


\section{PENDAHULUAN}

Pendidikan anak usia dini merupakan ranah pendidikan yang diperuntukan bagi anak berusia nol hingga enam tahun yang menjadi fondasi dasar dalam menstimulasi pertumbuhan dan perkembangan baik secara jasmani maupun rohani. (Shaleh \& Anhusadar, 2021) Pendidikan Anak Usia Dini merupakan pendidikan yang diselenggarakan untuk mengembangkan keterampilan yang merupakan pendidikan dasar serta mengembangkan diri secara utuh sesuai dengan asas pendidikan sedini mungkin dan sepanjang hayat. Pemerintah Indonesia sendiri menyatakan bahwa pendidikan anak usia dini terdiri atas tiga jalur yaitu jalur formal, non formal dan informal. Salah satu jalur pendidikan anak usia dini yang berada di lingkup PAUD Non Formal berupa kelompok bermain (UNDANG-UNDANG SISTEM PENDIDIKAN NASIONAL, 2003).

Menurut (Sujiono, 2012) Kelompok bermain merupakan layanan pendidikan anak usia dini di jalur non formal yang diperuntukan bagi anak usia tiga sampai enam tahun yang berfungsi untuk membantu meletakkan dasar-dasar ke arah perkembangan sikap, pengetahuan dan keterampilan yang diperlukan bagi anak usia dini dalam menyesuaikan diri dalam lingkungannya dan untuk pertumbuhan serta perkembangan selanjutnya, termasuk siap memasuki pendidikan dasar. Pada kelompok bermain anak distimulasi seluruh aspek perkembangannya seperti Nilai Agama Moral, Fisik Motorik, Bahasa, Kognitif, Sosial Emosional dan Seni. Khaironi (2018) menyimpulkan bahwa perkembangan pada anak usia dini tersebut tidak hanya terjadi pada saat itu saja akan tetapi terus berlanjut selama rentang kehidupan anak. Stimulasi yang diberikan untuk mengoptimalkan perkembangan tersebut pada usia dini akan mempengaruhi perkembangan anak selama hidupnya.

Pembelajaran dikemas dengan aktivitas menyenangkan yang dilakukan sambil bermain setiap harinya di lembaga. Menurut Indrijati (2017) Dalam praktek pendidikan anak usia dini memiliki prinsip-prinsip dan pendekatan yang digunakan diantaranya belajar sambil bermain, kedekatan dengan lingkungan, alam sebagai sarana pembelajaran, anak belajar melalui sensorinya, mengembangkan keterampilan hidup dan anak sebagai pembelajar aktif. Semua prinsip-prinsip dan pendekatan pembelajaran tersebut dikemas dalam kegiatan belajar yang menarik bagi anak yang disiapkan oleh pendidik.

Pandemi Covid 19 mengubah seluruh tatanan kehidupan manusia dalam segala aspek, tak terkecuali pada Kelompok Bermain. Setiap hari sistem belajar mengajar dilakukan dengan tatap muka tiba-tiba harus dirumahkan demi mencegah penyebaran Covid 19. Pandemi covid 19 memiliki dampak yang cukup signifikan dalam semua aspek kehidupan manusia termasuk dalam bidang pendidikan. Menurut Syah (2020) penutupan sementara lembaga pendidikan dilakukan sebagai upaya menahan penyebaran pendemi covid-19 di seluruh dunia yang berdampak pada jutaan pelajar. Melewati hari-hari dengan pandemi covid 19 hingga akhirnya masuk kepada sistem belajar di masa New Normal. Yang mana kedua fase memiliki cerita dan tantangan tersendiri pada setiap lini pendidikan tak terkecuali dengan kelompok bermain.

Lembaga Kelompok Bermain di Tanjung Harapan Kota Solok juga menggunakan kedua sistem belajar tersebut. Yang mana setiap lembaga dibebaskan untuk memilih sistem belajar yang digunakan di lembaga yang disesuaikan dengan kemampuan lembaga. Dari penerapan kedua sistem belajar ini memiliki kendala dalam pelaksanaannya. Untuk itu penting ada kajian khusus tentang problematika yang dihadapi anak, guru dan orang tua dalam penerapan sistem belajar daring dan sistem belajar luring yang dilaksanakan di Kelompok Bermain Kecamatan Tanjung Harapan Kota Solok. Dari hasil kajian ini diharapkan akan ada tindak lanjut kedepannya dalam meminimalisir kendala-kendala yang muncul dari system belajar daring dan luring ini. Dengan kata lain akan muncul upaya perbaikan mutu pembelajaran daring dan luring untuk anak jika situasi dan kondisi menuntut kembali hal tersebut dilaksanakan. Tujuan akhirnya adalah memberikan layanan yang optimal untuk tumbuh kembang anak dalam situasi luring maupun daring. 


\section{METODOLOGI}

Jenis penelitian yang digunakan pada penelitian ini adalah jenis penelitian kualitatif. Menurut (Sugiyono, 2008) metode penelitian kualitatif sering disebut metode penelitian naturalistik karena penelitiannya dilakukan pada kondisi yang alamiah (natural setting). Penelitian ini dilaksanakan pada Kelompok Bermain Shangridha yang sekarang sudah beralih nama menjadi PAUD SKB yang berada di Jl. Tembok, Kelurahan Nan Balimo, Kecamatan Tanjung Harapan Kota Solok. Subyek penelitian dalam penelitian Problematika Penerapan Sistem Belajar Daring dan Luring Terhadap Anak Pada Masa New Normal di PAUD Non Formal adalah anak kelompok A1, A2 dan B yang berjumlah 27 orang anak. Teknik pengumpulan data yang digunakan berupa observasi, wawancara dan dokumentasi. Adapun skema langkah-langkah pelaksanaan penelitian dapat digambarkan pada gambar 1 .

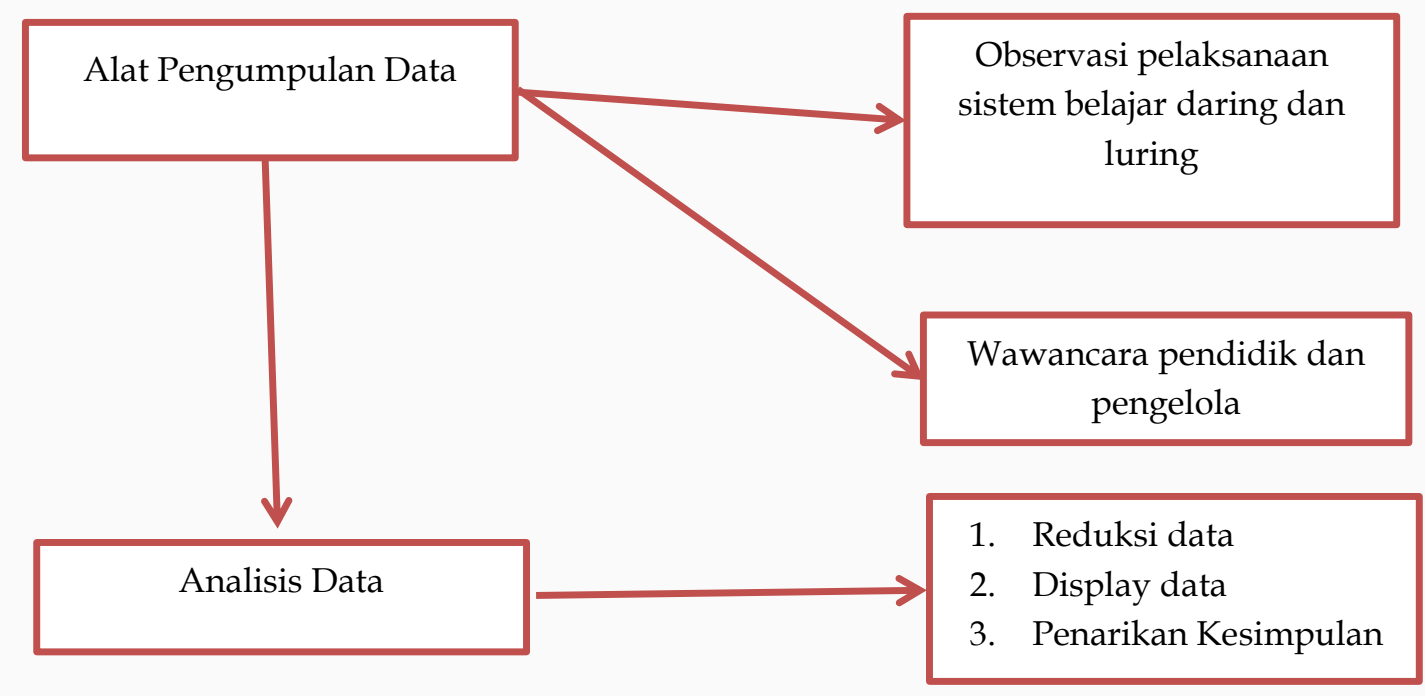

Gambar 1. Skema Langkah-Langkah Pelaksanaan Penelitian

\section{HASIL DAN PEMBAHASAN}

Penerapan sistem belajar daring dan luring dirasakan oleh seluruh komponen dalam satuan pendidikan, antara lain pendidik, pengelola, orang tua dan anak pada khususnya. Anak di Kelompok Bermain lah yang paling merasakan dampak langsung dari kebijakan sistem belajar di masa Pandemi covid 19 dan masa new normal. Hal yang sama juga dirasakan oleh Orang tua maupun pendidik. Sistem belajar yang diterapkan dengan pendekatan dalam jaringan maupun pendekatan luar jaringan memiliki beberapa kendala dalam penerapan yang berbeda-beda.

Berdasarkan hasil penelitian yang dilakukan peneliti di Kelompok Bermain Kecamatan Tanjung Harapan Kota Solok dapat digambarkan kendala yang di hadapi di dalam penerapan sistem belajar daring dan luring terhadap anak pada masa Pandemi covid 19 dan new normal di PAUD Non Formal.

\section{Kesesuaian Sistem Belajar dengan Prinsip Dan Metode Pembelajaran Anak Usia Dini}

(Indrijati, 2017) Salah satu prinsip pembelajaran anak usia dini adalah pembelajaran yang dilaksanakan melalui kegiatan belajar sambil bermain dan bermain seraya belajar. Dalam proses bermain anak di sana secara tidak langsung seluruh aspek perkembangan anak distimulasi baik kognitif, nilai agama dan moral, sosial emosional, bahasa, fisik motorik serta seni. Bermain untuk memberikan kebebasan pada anak untuk berimajinasi bereksplorasi dan menciptakan kreativitas. (Suryana, 2018) bermain kreatif memiliki ciri-ciri antara lain adanya fase berpikir kreatif, adanya karakteristik kreatif dan penerapan potensi kecerdasan jamak. 
Dalam proses belajar sambil bermain tersebut terdapat metode pembelajaran yang digunakan untuk mengoptimalkan seluruh aspek perkembangan anak. (Susanto, 2017) Metode pembelajaran pada anak usia dini antara lain terdiri dari metode bercerita, bernyanyi, karya wisata, demonstrasi, bermain peran, pemberian tugas, bercakap-cakap dan pemberian tugas. Selaras dengan penelitian (Botutihe et al., 2021) bahwa media atau aplikasi yang ratarata digunakan pendidik dalam membagi video tutorial kegiatan belajar untuk orangtua adalah aplikasi WhatsApp. Video pembelajaran tersebut dibuat oleh pendidik dalam memenuhi kebutuhan belajar anak.

Akan tetapi pada sistem belajar daring dan luring belum optimal memenuhi prinsipprinsip dan metode pembelajaran anak usia dini. Contoh prinsip pembelajaran anak usia dini yang belum terpenuhi adalah konsep belajar sambil bermain yang belum dapat menstimulasi seluruh aspek perkembangan anak pada satu kegiatan yang diberikan oleh pendidik. Dalam penggunaan metode pembelajaran pada sistem belajar daring dan luring belum menggunakan metode yang tepat karena keterbatasan waktu, alat serta keterbatasan kemampuan guru dalam meramu metode pembelajaran yang tepat. Yang mana metode yang paling sering digunakan adalah metode bercerita, tanya jawab dan pemberian tugas yang bersifat satu arah.

\section{Gaya Belajar Anak}

(Hernacki, 2002) gaya belajar adalah modal utama yang digunakan dalam mengembangkan kinerja pada pekerjaan, prestasi di sekolah dan dalam situasi antar pribadi. Apabila seorang individu mengetahui bagaimana cara orang lain menyerap dan mengolah informasi, maka hal tersebut dapat memudahkan orang tersebut untuk berkomunikasi dengan orang lain dan juga dapat mengambil langkah-langkah penting untuk membantu dirinya agar belajar lebih cepat dan mudah. (Indra Martha Rusmana \& Dwi Santi Wulandari, 2020) tanpa gaya belajar maka proses mengajar tidak akan berlangsung dengan baik, hal tersebut tidak membuat peserta didik lebih pandai akan tetapi dapat membantu peserta didik untuk menentukan cara belajar yang lebih efektif sehingga dapat mengelola pada kondisi apa, di mana, dan bagaimana ia dapat memaksimalkan. Belajar. Termasuk kondisi belajar di masa kondisi belajar anak usia dini di masa pandemi Covid 19 dan masa new normal yang biasanya anak belajar tatap muka lalu tiba-tiba dirumahkan hingga tatap muka kembali.

Menurut (Asrori et al., 2009) ada beberapa gaya belajar antara lain gaya belajar audio, gaya belajar visual dan gaya belajar kinestetik. (Saputri \& Afifah, 2019) gaya belajar audio merupakan gaya belajar individu yang biasa mengumpulkan informasi lebih baik melalui suara, musik, pidato dan komunikasi verbal. Gaya belajar visual adalah individu yang lebih banyak berfikir dalam bahasa gambar dari pada kata-kata serta gaya belajar kinestetik adalah belajar individu yang bisa belajar dengan banyak bergerak atau tidak bisa diam. Hal tersebut juga terdapat pada anak usia dini yang mana mereka memiliki gaya belajar yang beragam. Senada dengan (Saputri \& Afifah, 2019) menyatakan bahwa gaya belajar setiap anak usia dini berbeda dan dari perbedaan tersebut dapat diberikan pembelajaran yang sesuai.

Akan tetapi dalam pelaksanaan pembelajaran secara daring maupun luring belum dapat menstimulasi gaya belajar anak dengan maksimal. Pada pendekatan daring dapat memenuhi ketiga gaya belajar tersebut akan tetapi belum mewakili keseluruhan gaya belajar tersebut. Sedangkan pendekatan luring lebih banyak mewakili gaya belajar visual, sementara gaya belajar audio dan kinestetik kurang terwakili. Senada dengan (Satrianingrum \& Prasetyo, 2020) menyatakan bahwa kecenderungan gaya belajar pada sistem daring ialah gaya belajar visual dan tulisan. Pada masa new normal diterapkan dengan mengadakan pertemuan tatap muka terbatas, yang mana dengan sistem tersebut bisa sedikit menstimulasi gaya belajar anak tetapi belum optimal karena keterbatasan waktu pelaksanaan dengan pembagian anak per shift. Jadi gaya belajar yang dominan muncul saat daring adalah gaya belajar audio sedangkan pada saat luring adalahgaya belajar visual dan kinestetik.

\section{Kejenuhan Dalam Belajar}


(Eva Delfia, 2019) Pendidik berperan sebagai pendidik membuat pembelajaran yang aktif dan kreatif, dengan memberikan pengalaman bagi anak secara langsung melalui kegiatan-kegiatan selama proses pembelajaran. Seorang pendidik juga perlu melakukan berbagai usaha pendidikan dengan menciptakan lingkungan belajar yang menyenangkan bagi anak didiknya. Penggunaan media pembelajaran pada anak usia dini dapat menambah motivasi dalam belajar, sehingga anak mudah mengingat serta memahami isi materi yang disampaikan oleh pendidik. (Anggia \& Mahyuddin, 2020) didalam penelitiannya menyimpulkan bahwa terdapat perbedaan mengenai perilaku sosial anak usia dini yang disebabkan oleh suasana belajar yang menyenangkan dengan membangkitkan minat belajar untuk pembentukan karakter-karakter peserta didik dengan menyediakan berbagai media belajar agar peserta didik supaya tertarik mengikuti pembelajaran. Media pembelajaran menurut (Hamalik, 1989) adalah Alat, metode, dan teknik yang digunakan dalam rangka lebih mengefektifkan komunikasi dan interaksi antara pendidik dan siswa dalam proses pendidikan dan pengajaran di sekolah.

Pada sistem belajar daring yang menggunakan media video pembelajaran maupun lembar kerja yang dikirim pendidik dalam pelaksaannya menimbulkan kejenuhan pada anak jika media tersebut kurang dikemas semenarik mungkin. Pada video pembelajaran anak akan merasa jenuh sehingga menimbulkan ketidakmauan anak dalam mengikuti instruksi yang diberikan pendidik bahkan juga tidak mau untuk divideokan maupun di foto. Sedangkan pada pembelajaran sistem luring yang menggunakan lembar kerja, terkadang orang tua kurang memahami perintah pendidik sehingga menyebabkan anak mengalami kesulitan dalam mengerjakan kembar kerja sehingga anak tidak lagi mau mengerjakan sehingga proses belajar mengajar belum terlaksana optimal. Gambaran lembar kerja yang dikerjakan anak dapat dilihat pada gambar 2 .

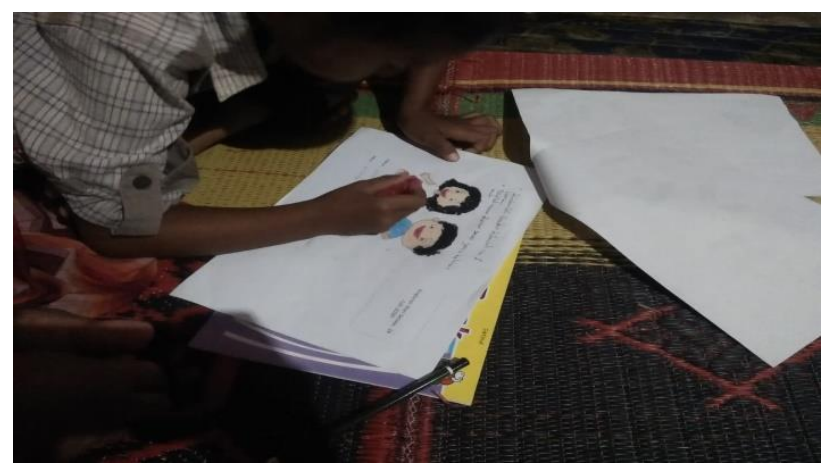

Gambar 1. Lembar Kerja yang di kerjakan oleh anak

\section{Peran Pendidik}

Bagi anak usia dini pendidik adalah figur idola setiap anak, setiap perkataan dan gerak gerik pendidik merupakan contoh teladan langsung. Dengan pendidik anak dapat menyalurkan seluruh emosi anak melalui bercerita. Akan tetapi pada sistem belajar di rumah, peran pendidik tidak berjalan seperti biasa hanya terjadi interaksi satu arah melalui video pembelajaran. Nurhafizah \& Moh.Kosnin (2017) menyatakan bahwa mendidik sesungguhnya adalah menjadi "modelling" bagi anak-anak. Selaras dengan hal tersebut Hadiyanto (2004) menyatakan bahwa pendidik merupakan manusia terhormat dalam segala aspek yang harus menjadi suri tauladan di kelas, maupun diluar keles, baik bagi peserta didik maupun masyarakat baik dari keampuan berpikir (ilmu pengetahuan) sikap tutur kata dan tingkah lakunya. Bagi anak usia dini pendidik merupakan idola yang selalu dinanti setiap hari.

Hal ini juga sependapat dengan penelitian (Syamsul Bahri, 2021) bahwa Seorang pendidik membutuhkan komunikasi yang luas terhadap peserta didik untuk memproses transformasi pesan berupa ilmu pengetahuan dan teknologi. (Maiza \& Nurhafizah, 2019) menyatakan bahwa pendidik merupakan suatu profesi yang sangat mempengaruhi hasil 
belajar anak didik, kemampuan seorang pendidik merupakan suatu gambaran yang hakikat dari prilaku pendidik atau tenaga kependidikan yang akan tampak sangat berarti dan berpengaruh terhadap lingkungan sekitarnya. Nandwijiwa \& Aulia (2020) dalam penelitiannya mengungkapkan bahwa masa pandemi COVID-19 peran pendidik di sekolah di gantikan langsung oleh orang tua yang mau tidak mau menjadi pendidik instan di rumah, orang tua bisa memberikan contoh dan teladan yang baik untuk anak dalam mengembangkan sosialnya, hal tersebut bisa di lakukan dengan mengajak anak untuk menyukai persahabatan, membimbing anak untuk mengikuti aturan, mengajarkan anak untuk lambat laun untuk tidak lagi berpusat pada kepentingan sendiri, membimbing anak untuk tidak mudah kecewa dan frustasi ketika mengalami kegagalan, membimbing anak untuk mengetahui kalau dirinya berbuat nakal, mengajar keterampilan bahasa, mengenalkan lingkungan kepada anak dan menanamkan nilai dan norma, budaya dan agama kepada anak.

Peran pendidik tidak dapat digantikan oleh media yang digunakan pada sistem belajar Daring maupun Luring, figur pendidik sebagai suri tauladan tidak dapat dilihat dan ditiru langsung oleh anak. Pada sistem belajar Daring, pendidik hanya berkomunikasi dengan anak melalui video pembelajaran yang dikirim Sedangkan pada sistem Luring peran pendidik digantikan oleh orang tua langsung. Dalam penerapan komunikasi dua arah dan proses pembelajaran yang mengembangkan seluruh aspek perkembangan anak berjalan kurang optimal. Terkadang dalam penafsiran video pembelajaran dan lembar kerja yang diberikan pendidik kepada orang tua tidak tersampaikan yang mengakibatkan orang tua menjadi enggan menggantikan tugas sebagai pendidik pengganti anak di rumah.

\section{Aktifitas Sosialisasi}

Sosialisasi merupakan kebutuhan pokok manusia selain makan minum dan pakaian dalam kehidupan sehari-hari. Merupakan sebuah fitrah manusia untuk berinteraksi sesama manusia begitu juga anak usia dini. Yolanda Mustika Fitri (2021) menyatakan bahwa perkembangan sosial identik dengan sosialisasi dan interaksi pada anak terhadap lingkungan dan emosi merupakan suatu kemampuan dari dalam diri seseorang terhadap respon tertentu. Bermain bersama teman merupakan hal yang paling ditunggu-tunggu oleh anak setelah dari rumah ketika sampai di sekolah. Peran teman sebaya sangat penting bagi anak usia dini, hal ini senada dengan penelitian yang dilakukan Utami (2018) mengenai pengaruh teman sebaya terhadap perilaku sosial anak menunjukan adanya perilaku kooperatif, bertoleransi, bertata karma, berempati, bersikap gigih serta dapat menghargai orang lain.

Mirnawati (2020) pada penelitiannya menyatakan bahwa terdapat hubungan yang signifikan yang terjadi ketika adanya interaksi teman sebaya dengan perilaku sosial anak usia 5-6 tahun yaitu dapat meningkatkan tingkah laku agar bisa menjadi sabar, dapat bekerjasama, dapat membantu dan menjadi lebih mandiri. Nandwijiwa \& Aulia (2020) orang tua juga memiliki peranan yang sangat penting sebagai tempat pertama kali seorang anak berinteraksi apabila lingkungan interaksi seorang anak bagus maka perkembangan sosial anak akan positif dan sebaliknya jika lingkungan sosial anak kurang bagus maka akan memberikan dampak negatif bagi anak. (Rina Bastian, Syur'aini, 2020) jika sosialisasi dalam keluarga belum terlaksana dengan baik maka perkembangan sosial anak usia dini juga tidak berkembang dengan baik dan begitu sebaliknya.

Akan tetapi dalam pelaksanaan sistem belajar daring dan luring anak hampir dapat dikatakan tidak optimal dalam bersosialisasi dengan teman dan pendidik. Anak terpaksa dirumahkan dan hanya melakukan kegiatan di sekitar rumah dan lembar kerja yang sudah diberikan guru. Anak secara otomatis dirumahkan dari segala aktifitas demi mencegah penularan virus covid 19. Anak hanya bersosialisasi via media daring yang digunakan lembaga seperti whatssapp group sementara media luring sosialisasi terjadi ketika anak dan orang tua menjemput lembar kerja ke sekolah maupun guru mengantarkan lembar kerja ke rumah masing-masing anak. Gambaran aktifitas anak yang didampingi guru dapat dilihat pada gambar 3. 


\section{Respon Orang Tua}

Dalam hal respon orang tua, pada sistem pembelajaran daring dan luring memiliki beragam reaksi dari orang tua terutama dalam pemanfaatan media Whattsapp Group (WAG) dan lembar kerja anak. Senada dengan Sit \& Assingkily (2020) pemanfaatan WAG dapat membantu pendidik untuk tetap menjalankan tugasnya memberi pengajaran pada anak. Harahap, Dimyati, \& Purwanta (2021) dalam memahami penjelasan pendidik terkadang kurang detail dan jelas sehingga membuat pemahaman orang tua berbeda-beda sehingga hasil yang disampaikan kepada anak juga terkadang berbeda pula. Bagi orang tua yang bekerja sesuai dengan hasil penelitian Syahrul \& Nurhafizah (2021) banyak orang tua yang tidak bisa mendampingi anaknya belajar dengan berbagai alasan yang mereka kemukakan seperti tidak mampu nya orang tua untuk mendampingi anak belajar disebabkan pekerjaan orang tua yang bekerja sebagai tenaga kesehatan dan sebagainya.

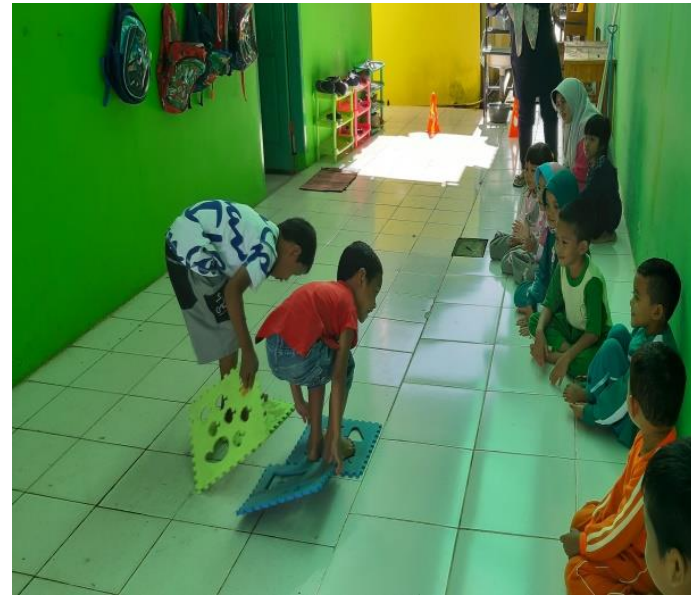

Gambar 3. Aktifitas bersama guru dan teman yang tidak bisa dilaksanakan seperti hari biasa

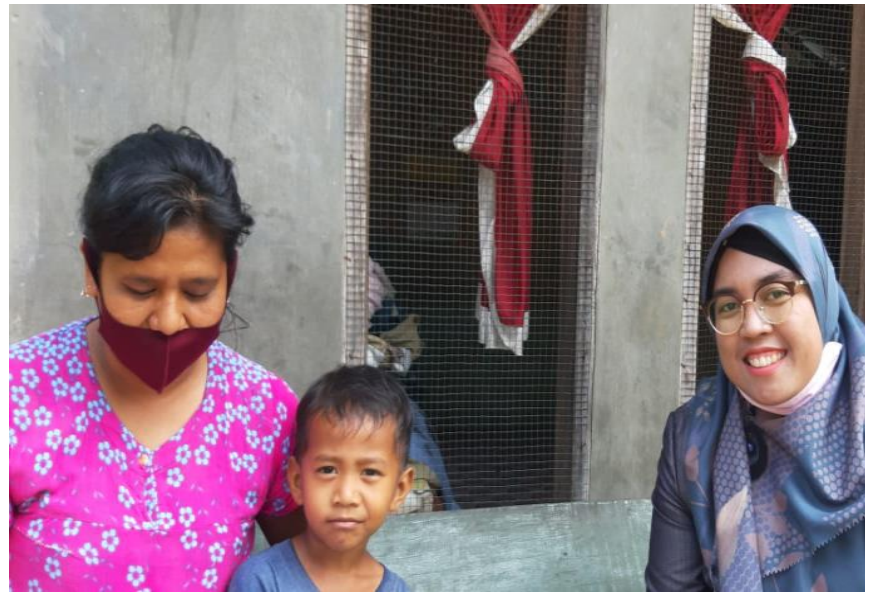

Gambar 4. Kunjungan Guru ke Rumah Anak

Respon yang diberikan oleh orang tua dalam pelaksanaan sistem belajar daring dan luring ini beragam. Ada yang menanggapi secara positif dan secara negatif bahkan ada yang tidak memberikan respon sama sekali. Berikut gambaran respon orang tua dapat dilihat pada tabel 1.

Tabel 1. Respon orang tua terhadap pembelajaran daring dan luring

\begin{tabular}{llclll}
\hline & \multicolumn{2}{c}{ Pembelajaran Daring } & & \multicolumn{3}{c}{ Pembelajaran Luring } \\
No & Bentuk Respon & $\mathbf{0}$ & No & \multicolumn{1}{c}{ Bentuk Respon } & $\%$ \\
\hline 1 & Positif & 18,1 & 1 & Positif & 25,9 \\
2 & Negatif & 38 & 2 & Negatif & 22,2 \\
3 & Tidak merespon & 44,4 & 3 & Tidak merespon & 33,3 \\
\hline
\end{tabular}

Bagi orang tua yang menanggapi secara positif tentu pembelajaran yang diberikan guru dapat terlaksana walaupun belum optimal. Namun bagi orang tua yang menanggapi respon secara negatif bahkan tidak menanggapi sama sekali tentu menyebabkan sistem pembelajaran tidak dapat berjalan di tengah kondisi seperti ini. Terkadang ketika respon dari orang tua tidak ada di WAG lembaga maka guru secara otomatis guru turun langsung untuk mengantarkan lembar kerja anak ke masing-masing rumah. Ketika pengumpulan lembar kerja anak terkadang orang tua tidak mengantarkan kembali sehingga tugas menumpuk dan pada akhirnya tidak dikerjakan oleh anak. Kondisi kunjungan guru ke rumah anak dapat diilustrasikan pada gambar 4. Masalah ekonomi juga salah satu penyebab dari tidak adanya 
DOI: 10.31004/obsesi.v6i4.2206

respon dari daring karena keterbatasan HP android dan pembelian paket data. Yang mana orang tua lebih mengutamakan kebutuhan pokok di keluarga dibandingkan hal tersebut.

\section{SIMPULAN}

Penerapan Sistem Belajar Daring dan Luring Terhadap Anak Usia Kelompok Bermain memiliki beberapa kendala dalam penerapannya antara lain penerapan sistem belajar daring dan luring belum optimal memenuhi prinsip-prinsip pembelajaran anak dan metode pembelajaran anak usia dini, belum optimal menstimulasi gaya belajar anak karena dominan hanya memakai gaya belajar audio dan visual, media pembelajaran yang digunakan menimbulkan kejenuhan dalam belajar karena saat daring dominan memakai WAG dan luring dominan memakai lembar kerja yang diberikan kepada anak, Peran pendidik tidak dapat digantikan oleh media, proses sosialisasi dengan teman dan pendidik tidak berjalan optimal serta Respon Orang Tua dalam pelaksanaan pembelajaran umumnya kurang mendukung proses pembelajaran anak yang efektif seperti kurang respon di grup wa, tidak mengembalikan lembar tugas anak bahkan tidak menggubris sama sekali walaupun sudah dikunjungi oleh pendidik. Hasil penelitian ini dapat dijadikan referensi ke depannya untuk membuat sistem pembelajaran yang yang ramah anak dalam menghadapi situasi darurat yang tiba-tiba akan terjadi ke depannya sehingga anak tidak kehilangan kesempatan dalam belajar.

\section{UCAPAN TERIMA KASIH}

Terima kasih penulis ucapkan kepada PAUD SKB Kota Solok yang telah memberikan kesempatan pada peneliti untuk meneliti tentang kendala yang dihadapi selama melaksanakan pembelajaran sistem daring dan luring. Serta ucapan terima kasih kepada Dosen Pembimbing Nurhafizah,S.Pd, M.Pd, Ph.D yang telah banyak memberikan sumbangsih saran dan masukan yang membangun dalam penelitian ini.

\section{DAFTAR PUSTAKA}

Anggia, S., \& Mahyuddin, N. (2020). Pengaruh Penggunaan Media Film Animasi Upin dan Ipin Terhadap Perilaku Sosial Anak di Taman Kanak-Kanak Aisyiyah Padang Panjang. Jurnal Pendidikan Tambusai, 4(1), 428-433. https:// doi.org/10.31004/obsesi.v4i1.358

Asrori, A., Hidayat, T., \& Nugroho, A. A. (2009). Hubungan kecerdasan emosi dan interaksi teman sebaya dengan penyesuaian sosial pada siswa kelas VIII program akselerasi di SMP Negeri 9 Surakarta. Wacana, 10, 1-25.

Botutihe, S. N., Smith, M. Bin, Kasan, I. A., \& Hilala, R. (2021). Strategi Pembelajaran Physical Distancing PAUD dalam Menghadapi Pandemi Covid19. 5(2), 1536-1543. https://doi.org/10.31004/obsesi.v5i2.919

Eva Delfia, N. N. (2019). Profesionalisme Guru Pendidikan Anak Usia Dini Dalam Menggunakan Media Pembelajaran. Pendidikan Tambusai, 3(1), 1049-1057.

Hadiyanto. (2004). Mencari Sosok Desentralisasi Manajemen Pendidikan Di Indonesia. Rineka Cipta.

Hamalik, O. (1989). Media Pendidikan. Citra Aditya.

Harahap, S. A., Dimyati, \& Purwanta, E. (2021). Problematika Pembelajaran Daring dan Luring Anak Usia Dini bagi Guru dan Orang tua di Masa Pandemi. Jurnal Obsesi: Jurnal Pendidikan Anak Usia Dini, 5(2), 1825-1836. https://doi.org/10.31004/obsesi.v5i2.1013

Hernacki, B. D. P. \& M. (2002). Quantum Learning; membiaskan Belajar Nyaman dan Menyenangkan. Kaifa.

Indra Martha Rusmana, \& Dwi Santi Wulandari. (2020). Pengaruh Gaya Belajar Dan Kecerdasan Logika Matematika Terhadap Prestasi Belajar Matematika. Jurnal 
Lebesgue : Jurnal Ilmiah Pendidikan Matematika, Matematika Dan Statistika, 1(2), 7681. https:// doi.org/10.46306/lb.v1i2.18

Indrijati, H. (2017). Psikologi Perkembangan dan Pendidikan Anak Usia Dini Sebuah Bunga Rampai (I). Kencana.

Khaironi, M. (2018). Perkembangan anak usia dini. Jurnal Golden Age Hamzanwadi University. https://doi.org/10.29408/goldenage.v2i01.739

Maiza, Z., \& Nurhafizah, N. (2019). Pengembangan Keprofesian Berkelanjutan dalam Meningkatkan Profesionalisme Guru Pendidikan Anak Usia Dini. Jurnal Obsesi : Jurnal Pendidikan Anak Usia Dini, 3(2), 356. https:// doi.org/10.31004/obsesi.v3i2.196 Mirnawati, M. (2020). Hubungan Interaksi Teman Sebaya dengn Perilaku Sosial Anak Usia 56 Tahun di TK Paras Jaya Palembang. PERNIK: Jurnal Pendidikan Anak Usia Dini, 2(1), 1. https://doi.org/10.31851/pernik.v2i2.4092

Nandwijiwa, V., \& Aulia, P. (2020). Perkembangan Sosial Anak Usia Dini pada Masa Pandemi COVID-19. Jurnal Pendidikan Tambusai, 4(3), 3145-3151.

Nurhafizah, N., \& Moh.Kosnin, A. (2017). The Development of Children's Social-Emotional Competences: A Case Study in UNP's Labschool-Kindergarten, Padang Indonesia. 58, 369-374. https:// doi.org/10.2991/icece-16.2017.64

Rina Bastian, Syur'aini, I. (2020). Sumatera Barat. Pengaruh Sosialisasi Dalam Keluarga Terhadap Perkembangan Sosial Anak Usia Dini Di Masyarakat Desa Koto Lamo Sumatera Barat, 2(1), 16-25.

Saputri, I. A., \& Afifah, D. R. (2019). Gaya Belajar Anak Usia Dini Kelompok B Tk Margobhakti Kota Madiun Isna. Jurnal Care, 6(2).

Satrianingrum, A. P., \& Prasetyo, I. (2020). Persepsi Guru Dampak Pandemi Covid-19 terhadap Pelaksanaan Pembelajaran Daring di PAUD. Jurnal Obsesi: Jurnal Pendidikan Anak Usia Dini, 5(1), 633. https://doi.org/10.31004/obsesi.v5i1.574

Shaleh, M., \& Anhusadar, L. (2021). Kesiapan Lembaga PAUD dalam Pembelajaran Tatap Muka pada New Normal. Jurnal Obsesi : Jurnal Pendidikan Anak Usia Dini, 5(2), 21582167. https:// doi.org/10.31004/obsesi.v5i2.1139

Sit, M., \& Assingkily, M. S. (2020). Persepsi Guru tentang Social Distancing pada Pendidikan AUD Era New Normal. Jurnal Obsesi : Jurnal Pendidikan Anak Usia Dini, 5(2), 1009 1023. https://doi.org/10.31004/obsesi.v5i2.756

Sugiyono. (2008). Metode Penelitian Pendidikan Pendekatan Kuantitatif, Kualitatif, dan R \& D (6th ed.). Alfa Beta.

Sujiono, Y. N. (2012). Konsep Dasar pendidikan anak usia dini (teori dan praktik pembelajaran). Indeks.

Suryana, D. (2018). Pendidikan Anak Usia Dini: Stimulasi dan Aspek Perkembangan Anak.

Susanto, A. (2017). Pendidikan anak usia dini. Bumi Aksara.

Syah, R. H. (2020). Dampak Covid-19 pada Pendidikan di Indonesia: Sekolah, Keterampilan, dan Proses Pembelajaran. SALAM: Jurnal Sosial Dan Budaya Syar-I, 7(5). https://doi.org/10.15408/sjsbs.v7i5.15314

Syahrul, S., \& Nurhafizah, N. (2021). Analisis Pengaruh Pola Asuh Orang Tua Terhadap Perkembangan Sosial dan Emosional Anak Usia Dini Dimasa Pandemi Corona Virus 19. Jurnal Basicedu, 5(2), 683-696. https:// doi.org/10.31004/basicedu.v5i2.792

Syamsul Bahri, N. A. (2021). Kebijakan Pendidikan Dalam Stabilitas Mutu Pembelajaran Anak Usia Dini Era Pandemi Disease. Continuous Education: Journal of Science and Research, 2(2), 14-22. https://doi.org/10.51178/ce.v2i2.224

Undang-Undang Sistem Pendidikan Nasional, (2003).

Utami, D. T. (2018). Pengaruh Lingkungan Teman Sebaya Terhadap Perilaku Sosial Anak Usia 5-6 Tahun. Generasi Emas, 1(1), 39. https://doi.org/10.25299/ge.2018.vol1(1).2258

Yolanda Mustika Fitri, N. N. (2021). Pengaruh Metode Gerak dan Lagu Terhadap Perkembangan Sosial dan Emosional Anak di Kota Padang. Jurnal Basicedu, Volume 5 N. https://doi.org/10.31004/basicedu.v5i2.779 